東京湾奥部谷津干潟の 1986-87 年冬期における底質環境ならびに

マクロベントスの生息状況と垂直分布

\title{
Sediment Conditions and Macro-zoobenthos Distribution in the Winter of 1986-87 on the Yatsu Tidal Flat of Innermost Tokyo Bay.
}

\author{
風呂田利夫・鈴木嘉平 \\ 東邦大学理学部海洋生物学研究室. $\bar{\tau} 274-8510$ 千葉県船椅市三山 2-2-1
}

Toshio FUROTA and Kahei SUZUKI

Department of Biology, Faculty of Science, Toho University, Miyama 2-2-1, Funabashi, Chiba 274-8510, Japan.

\begin{abstract}
The Yatsu Tidal Flat is a small tidal wetland of approximately $40 \mathrm{ha}$, located in the middle of landfill along the northern shore of Tokyo Bay. The flat is connected to the bay through two narrow tidal waterways. Originally, extensive tidal flats rimmed the entire coast of Tokyo Bay. Almost all of these, however, have been landfilled, and the Yatsu Tidal Flat was left stranded in the center of the landfill. This small flat is now the most important feeding habitat for shorebirds along the northern bay. The flat was registered under the Ramsar Convention in 1983. Macrobenthic animals are vital prey for shorebirds, and they are also important elements in the tidal flat ecosystem. Observations of the macrobenthic fauna at the Yatsu Tidal Flat were conducted in 1974-75, one year after the flat was enclosed by the surrounding landfill, by a team of researchers. A similar survey was later implemented in 1994-95 by the Japanese Environmental Agency and local governments. Environmental conditions of the flat, such as particle size distribution of the sediment and nutrient load, changed greatly between these surveys. The authors also conducted observations at the Yatsu Tidal Flat during the winter of 198687. Both the horizontal distribution of macrobenthic animals and their vertical distribution in the sediment column were observed. The results were correlated with sediment conditions (redox potential and particle size). The macrobenthic fauna was dominated by the polychaetes Tylorrhynchus heterochaetus and Neanthes succinea. Tylorrhynchus heterochaetus was restricted to the margin of the flat, which consisted of fine-sandy aerobic sediments; $N$. succinea was found in the central part of the flat, which consisted of reduced muddy sediments. In general, the number of species tended to decrease in more reduced sediments, but the largest number of species was found in an area where the sediment was heavily reduced in its deeper layers but aerobic near the surface. In addition, oligochaetes and several species of small polychaetes, such as Sigambra sp. and Capitella $\mathrm{sp}$., occurred in very reduced sediment (Eh less than $-200 \mathrm{mV}$ ). The results of our observations indicate that aerobic conditions near the surface are important in maintaining the macrobenthic population in an organically polluted tidal wetland. A comparison of the results of the three surveys that have been conducted during the 20 years since the flat was enclosed shows that the diversity of the macrobenthos increased gradually, but that the size of the nereidid polychaete population, which provides the most important food source for shorebirds, has decreased in recent years. This decrease may be due to a reduction in the loads of organic matter and inorganic nutrients entering the flat.
\end{abstract}

Key Words: Macrobenthos, Ramsar Convention, Redox potential, Tokyo Bay, Vertical distribution in sediment, Wetland productivity, Yatsu Tidal Flat.

\section{はじめに}

東京湾最奥部に位置する千葉県習志野市谷津周辺の海岸 には，かつて東京湾に面して沖合約 $2 \mathrm{~km}$ にわたる開放的 な砂質干潟が広がっていた。しかし，1970 年以降の埋め立

Received 18 Jan 1999 Accepted 18 May 1999
てにより干潟部のほとんどが消失し，現在ではかつての干 潟面の岸奇りの一部が埋立地により囲まれた状態で残るの

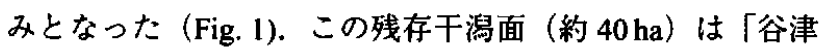
干潟」と呼ばれ, シギ・チドリ類の飛来が多いことから 1983 年「特に水鳥の生息地として国際的に重要な湿地に関 する条約（ラムサール条約）」の指定登録地となり，現在 では野鳥とくに海浜鳥類の保護区として習志野市により管 理されている。 


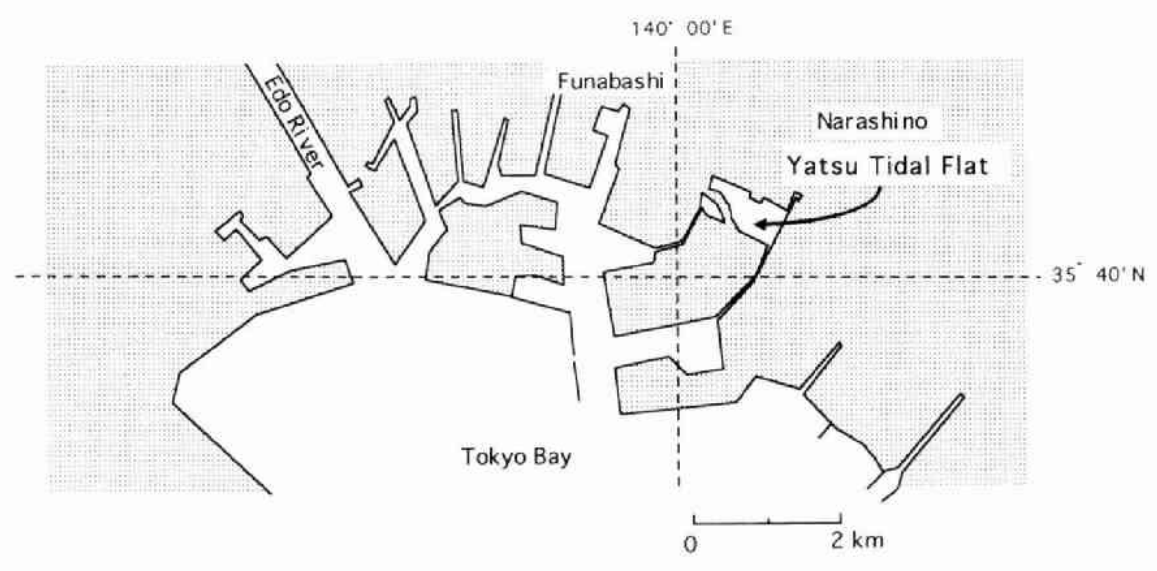

Fig. 1. Location of Yatsu Tidal Flat along the innermost of Tokyo Bay.

マクロベントスは干潟生態系の中で最も重要な生物群で あり，生物生产や物質循環など干潟生態系を質的に評価す るうえでその生息状況の把握が不可欠である（例えば佐々 木 1994a, b)。また現在，埋め立てや護岸化などにより劣悪 化した海岸環境の修復を目的に人工的な干潟の造成も試み られており，マクロベントスの生息状況は環境修復度合の 評価指標としても用いられる(今村ほか 1993; 碇ほか1 1996). 谷津干潟のように環境が人為的に極度に変更された干潟で のマクロベントス群集の生息に関する研究は, 開発の干潟 環境に対する影響，ならびに干潟環境の再生と修復に関す る基本的な知見として重要である.さらに，谷津干潟をシ ギ・チドリ類などの海浜鳥類保護の場として管理するため にも，鳥類の主要䬳資源であるマクロベントスの生息状況 把握が求められる.

これまでの谷津干潟に求けるマクロベントスの生息状況 に関しては，谷津干潟が閉鎖形状になった䪨 1 年後の 1974 年から 1975 年にわたる民間研究グループ (干潟研究会 1975)と，その䄪 20 年後の 1995 年から1996 年にかけて の行政（環境庁ほか1996）による調查が行われており，そ の結果はそれぞれ事業報告書として発表されている。しか しこの間に干渴環境は大きく変化しており，1974 年では埋 立て工事中に排出された浮泥の堆積によりその底質は軟泥 状態であったが, 1995 年には干潟域の約半分が砂泥質，ま た一部は砂質となり，したいに砂質化が進んできた（環境 庁ほか 1996)。ささらにこの間, 干潟への家庭排水の流入が 停止され，干渴への有機物や無機栄養水質負荷が大きく低 下した。このように人為改変を受け，底質ならびに水質が 大きく変化しつつある干潟の環境変化を把握し, その保全 策を考えるうえで，マクロベントス生息状況の長期的変遷 の継続的調查研究が不可欠である.

干潟のマクロベントスは一般的に底質内に生息する内在 生動物（infauna）であり，底泥内垂直分布は種特異的で， 分布下限は底泥表面下 $60 \mathrm{~cm}$ 以深に及ぶ (風呂田 1996a). またその垂直分布は有機污濁による底質の還元化の影響を 受け，極度な還元化はマクロベントスの生息を酸素条件の
良好な近表層へと限定させる (Peason \& Rosenberg 1978). さらに，マクロベントスを主要な慨とするシギ・チドリ類 の採取可能な慨動物は彼らのくちばしの長さと関倸してお り (長谷川 1980; Zwarts \& Wanink 1984), ベントスの分布 深度は餌資源としての価值に大きく影響する。したがって, 谷津干潟のように家庭排水による底質の有機污濁が懸念さ れ，また野鳥採食場としての価值が求められている干潟に おいては, マクロベントス各種の底質内での深度分布の把 握も必要となる.

本文では，谷津干潟に家庭排水の流入が続いていた 1985 年から1986 年にかけての冬期のマクロベントスの水平な らびに垂直分布と, 底質の粒度と酸化還元電位の調查結果 を報告し、マクロベントスの生息状況と長期的変遷につい て野鳥の慨資源問題も含めて議諭する.

\section{調査地ならびに調査方法}

谷津干湯 $\left(35^{\circ} 41^{\prime} \mathrm{N}, 140^{\circ} 01^{\prime} \mathrm{S}\right)$ は本街地となった埋立地に曲ま 九て存在し，2本の水路で潮汐に伴う東京渞上の海水交換が行わ れている (Fig. 1)。干潟の面積は䄪 40 haで，干潮時には一部の夕 リーク在除き T.P. (東京湾平均海面) $-20 \mathrm{~cm}$ でほほ全面的に露出 する(環境打ほか 1996)。

今回の調查当時 (1986 年)，底質は標高のやや高い東側で砂泥 もしくは砂質であり，やや低い西側では泥犋となっていた（Fig. 2)。底質の保水性は高く，干出時でも干潟面のほほ全域が湿洞な 状態に保た机ていた。また，家庭排水が潟東側の数々所と北側 1 カ所から流入していた。

調查測点は底質・水質特性を考虑して5ヶ所設けた (Fig. 2). St. 5 の近くには排水口があり，今回の調查の中で家庭排水の影缽 を最も强く受ける所であった。各測点において，内径 $10 \mathrm{~cm}$ の塩 化ヒニール製バイプにより深さ $60 \mathrm{~cm}$ までの底泥を13回（計 $0.1 \mathrm{~cm}^{2}$ ) 採取した。採取した底泥を表層より $10 \mathrm{~cm} こ と に 6$ 層に 分け，1 mmメッシュのふるいにかけ，残留物を $10 \%$ のホルマリ ンで固定した，固定した残留物を実験空に持ち㷌り，水洗後動物 のみ老拾い集め, 実体顕微鏡下で同定し, 個体数を求めた，各種 ごとに，ろ紙で余分な水分を除いた後，直示天科により湿重量を $1 \mathrm{mg}$ 精度で求めた。 


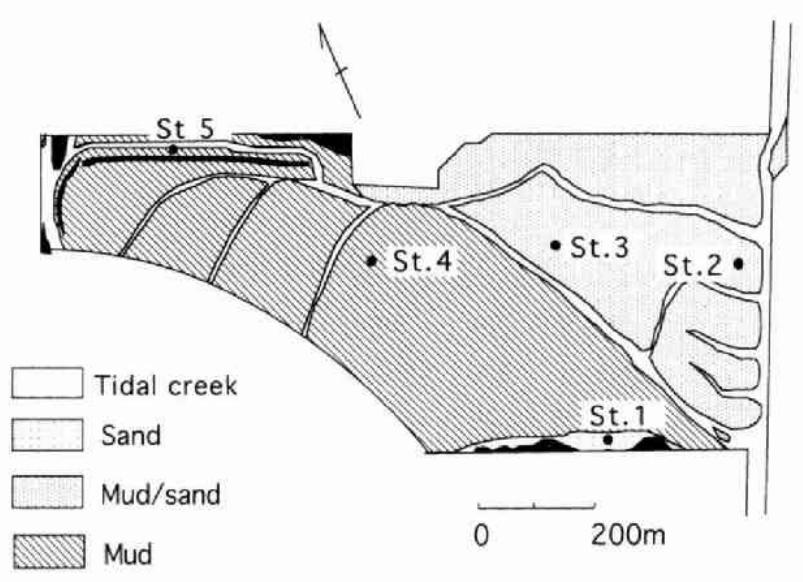

Reed (Phragmites australis) belt

Fig. 2. Sediment character and observation stations (St. 1-5) in the Yatsu Tidal Flat.

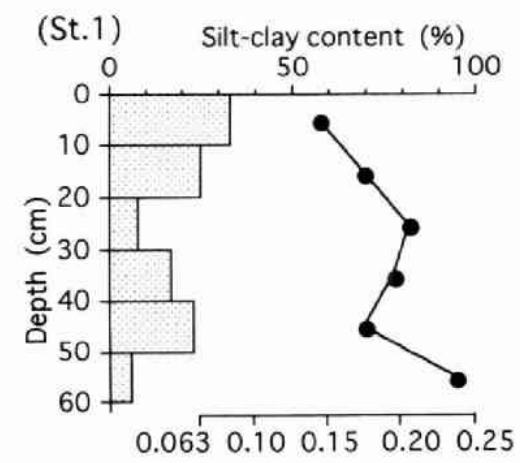

(St.2)

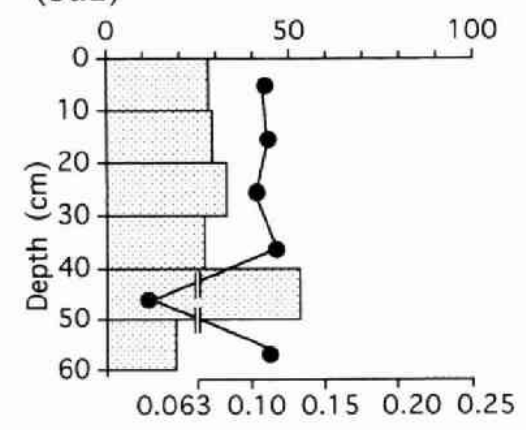

(St.3)

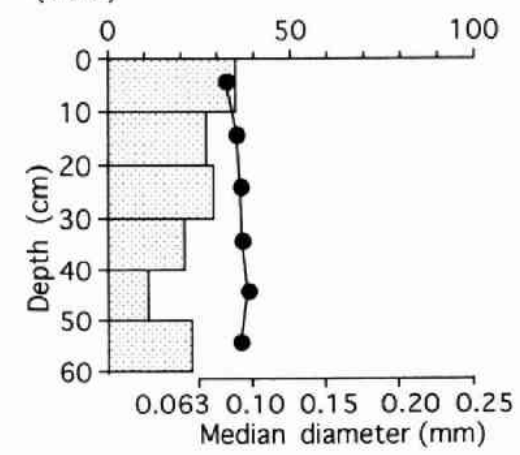

また各層の底泥を $100 \mathrm{ml}$ のビンにつめ, 実験室に持ち㷌り直ち に酸化還元電位計（東严電波社製， RM-1K) で酸化還元電位を測 定し，標準水素電極に対する電位差（Eh）に換算した。またこの 底泥から吸引ろ過により間隙水を採取し，モールの銀滴定法 (気 象庁 1970〉により塩分濃度を湘定した。さらに残った底泥を用 い, 底質の粒度分析（日本海洋学会 1986）を行った，今回の調査 は1986 年 12 月 10 から䍿年 1 月 29 日の冬期に 5 回に分けて行な われた。

\section{結 果}

\section{底質特性}

測点ごとに各層の底質粒度組成をFig. 3, 酸化還元電位 (Eh) の垂直変化を Fig. 4, また, 間隙水の塩分濃度変化 を Fig. 5 に示す.

St. 1 の底質は灰白色の細砂で固くしまっており, 表面に

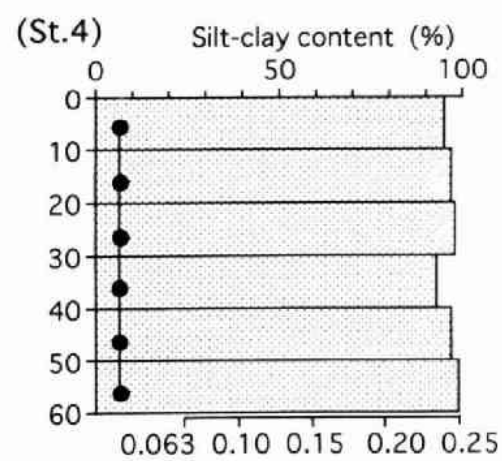

(St.5)

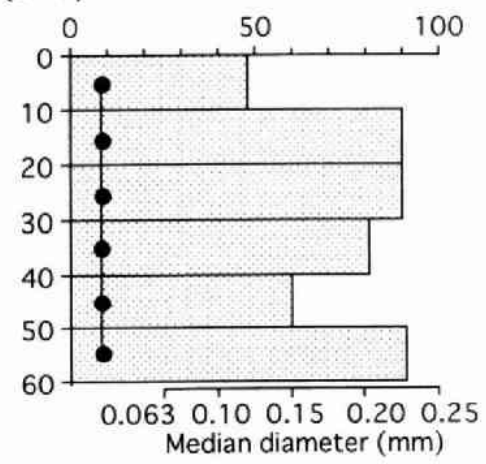




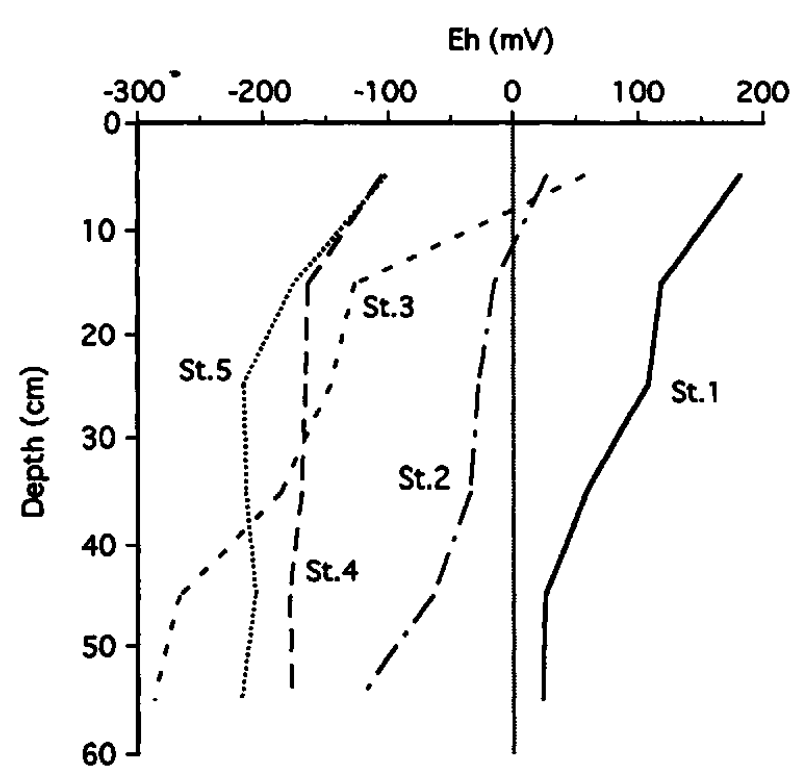

Fig. 4. Change in redox potential profiles through the sediment column at each station in the Yatsu Tidal Flat.

は直径数 $\mathrm{mm}$ の小孔が密に開いていた。中央粒径值は $0.15 \sim 0.23 \mathrm{~mm}$, 粒径 $0.0063 \mathrm{~mm}$ 以下の泥分量は 6 33\% で，表面ほど泥分が增加の傾向にあった．Eh は 25 183 $\mathrm{mV}$ を示し，全層でプラス値であった，間隙水の塩分濃度 は 21 26 psuで, 下部で増加の傾向があるものの変化は少 なかった。

St. 2 の底土は灰色の軟泥で, 中央粒径値は $0.063 \mathrm{~mm}$ 以 下 0.125 mm，含泥量は 19 53\%の間であった．Ehは表 層を除いてマイナス值を示し，深くなるにつれて低下し $60 \mathrm{~cm}$ ではー $125 \mathrm{mV}$ を示した。塩分濃度はSt. 1 とほほ同 様の変化を示し，25 28 psuの間で深部で増加する傾向を 示した。

St. 3 の底泥は灰色の砂泥で, 二枚貝や巻貝の死款を含ん でいた，中央粒径值は $0.07 \sim 0.1 \mathrm{~mm}$, 含泥量は 10 34\%の 間で, $40 \sim 50 \mathrm{~cm}$ で最も粗かった，Ehは表層でプラス值を 示したものの，深くなるにつれ大きく滅少し，最深部では $-285 \mathrm{mV}$ の強い還元状態を示した. 塩分濃度は 27 32psu を示し，前の 2 測点とは逆に表層で増加した。

St. 4 の底土は灰色の軟泥で, 含泥量が 93 98\% と極めて 高く, $0.063 \mathrm{~mm}$ 以上の砂分はほとんど含まれていなかっ た.Eh は全層でマイナス值を示し，20 30 cm 以深では約 $-170 \mathrm{mV}$ であった。塩分濐度は $10 \sim 20 \mathrm{~cm}$ で $29 \mathrm{psu}$ を示し たが, $30 \mathrm{~cm}$ 以深では $10 \mathrm{psu}$ 以下に低下した。

St. 5 の底土は黒色の軟泥で, 植物遺体片やビニール片を 含み, 硫化水素臭を発していた. $0.063 \sim 0.25 \mathrm{~mm}$ の細砂も 含まれるが, 表面層を除いて含泥量は 50\% 以上であった。 Ehは全層で還元状態で, とくに 20 30 cm 以深では -200 $\mathrm{mV}$ 以下の強い還元性を示した。塩分濃度は表单から 40 $50 \mathrm{~cm}$ までは約 $22 \mathrm{psu}$ であったが, 50 60 cm では $17 \mathrm{psu}$ ま で低下した。

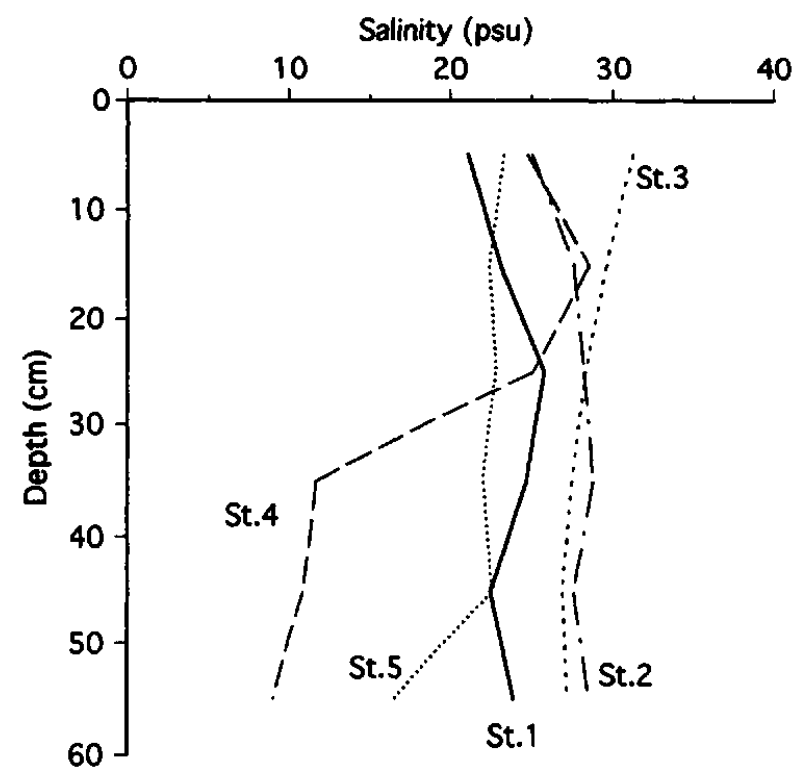

Fig. 5. Change in interstitial salinity through the sediment column at each station in the Yatsu Tidal Flat.

\section{マクロベントス}

今回採集され分類されたマクロベントスは多毛類（Polychaeta） 9 種, 二枚貝類 (Bivalvia) 2 種, 甲殻類 (Crustacea) 3 種の計 14 種, また同定が困難で複数種からなる動物群と して筫毛類 (Oligochaeta) 1 群, 多毛類 2 群 (Sabellidae と Spionidae), 甲殻類 2 群 (Cumacea と Gammaridea), 双翅 目幼生（Diptera larva）1 群の計 6 群であった（Table 1).

各測点におけるマクロベントスの垂值分布を Fig. 6 に示 す. St. 1 では個体数ではイトメ Tylorrhynchus heterochaetus (Quatrefages)，ドロクダムシの 1 種 Corophium sp., 双翅目 幼生, 筫毛類が 10 個体 $/ 0.1 \mathrm{~m}^{2}$ 以上出現し, 湿重量ではイ トメ，チゴガニIlyoplax pusilla (de Haan), 双翅目幼生が $0.1 \mathrm{~g} / 0.1 \mathrm{~m}^{2}$ 以上出現した。とくにイトメは全湿重量の $98.9 \%$ を占め, $20 \sim 30 \mathrm{~cm}$ に分布が集中し $50 \mathrm{~cm}$ までの比較 的深い層まで分布していた。

St. 2 では個体数ではアシナガゴカイ Neanthes succinea (Frey et Leuckart), ヨツバネスピオ Paraprionospio sp. (A 型), Capitella sp., Heteromastus sp., ドロクダムシの 1 種が 10 個体 $/ 0.1 \mathrm{~m}^{2}$ 以上出現し, 湿重量ではアシナガゴカイ, Heteromastus sp., チゴガニが $0.1 \mathrm{~g} / 0.1 \mathrm{~m}^{2}$ 以上出現した. 20 $\mathrm{cm}$ 以浅でベントス個体数が多く, Heteromastus sp. を除き 0 10 cmの表面近くに集中的に分布していた。

St. 3 ではアシナガゴカイ, Paraprionospio sp. (A 型), Sigambra sp., ケヤリ科多毛類 (Sabellidae), ドロクダムシ の 1 種が 10 個体 $/ 0.1 \mathrm{~m}^{2}$ 以上, 湿重量ではアシナガゴカイ, Heteromastus sp., Sigambra sp., $ア サ リ R$ Ruditapes philippinarum (A. Adams et Reeve), が $0.1 \mathrm{~g} / 0.1 \mathrm{~m}^{2}$ 以上出現した. この測点の優占種であるアシナガゴカイは $20 \mathrm{~cm}$ 以浅に多 く，より下部では少なかった，下部ではヨコエビ類（Gammaridea) や Sigambra sp., Polydora sp. など小型のものが多 
Table 1. Occurrence of macrobenthic animals in the Yatsu Tidal Flat. No. of individuals (wet $\mathrm{g}$ ) $/ 0.1 \mathrm{~m}^{2} .+$, less than 0.001 .

\begin{tabular}{|c|c|c|c|c|c|}
\hline Animals & St. 1 & St. 2 & St. 3 & St. 4 & St. 5 \\
\hline OLIGOCHAETA & $16(0.005)$ & $5(+)$ & & & $52(+)$ \\
\hline \multicolumn{6}{|l|}{ POLYCHAETA } \\
\hline Neanthes succinea & $1(0.008)$ & $81(3.421)$ & $190(7.543)$ & $155(20.227)$ & $25(3.373)$ \\
\hline Tylorrhynchus heterochaetus & $95(49.470)$ & & & & \\
\hline Spionidae & $8(+)$ & & & & \\
\hline Paraprionospio sp. (A) & & $15(0.007)$ & $33(0.005)$ & $3(+)$ & \\
\hline Pseudopolydora kempi & & $2(+)$ & & $1(0.002)$ & \\
\hline Polydora sp. & & $3(0.018)$ & $4(0.005)$ & & \\
\hline Capitella sp. & & $11(0.018)$ & $6(0.017)$ & & $3(+)$ \\
\hline Heteromastus sp. & & $34(1.975)$ & $16(0.476)$ & & \\
\hline Sigambra sp. & & & $14(0.107)$ & & \\
\hline Eteone sp. & & $2(0.004)$ & $2(0.005)$ & & \\
\hline Sabellidae & & & $24(0.047)$ & & \\
\hline \multicolumn{6}{|l|}{ MOLLUSCA } \\
\hline Ruditapes phillipinarum & & & $5(0.126)$ & & \\
\hline Meretrix lusoria & & & $1(0.019)$ & & \\
\hline \multicolumn{6}{|l|}{ CRUSTACEA } \\
\hline Cumacea & $1(+)$ & & $3(+)$ & $48(0.018)$ & \\
\hline Gammaridea & $1(+)$ & & $7(+)$ & & \\
\hline Corophium sp. & $27(0.022)$ & $38(0.049)$ & $15(+)$ & $3(+)$ & $1(+)$ \\
\hline Ilyoplax pusilla & $1(0.201)$ & $3(1.268)$ & & & $1(0.461)$ \\
\hline Upogebia major & $1(0.021)$ & & & & \\
\hline \multicolumn{6}{|l|}{ INSECTA } \\
\hline Diptera larvae & $23(0.104)$ & $13(0.070)$ & $1(0.011)$ & & $3(+)$ \\
\hline Total & $174(49.831)$ & $207(6.830)$ & $321(8.361)$ & $210(20.247)$ & $85(3.834)$ \\
\hline
\end{tabular}

く採集された。この測点は今回の調査のなかで出現種数が 最も多く，また垂直的な分布も種間での変化が最も大きい 測点であった.

St. 4 ではアシナガゴカイとクーマ類 (Cumacea) だけが 10 個体 $/ 0.1 \mathrm{~m}^{2}$ を超え, 湿重量ではアシナガゴカイだけで全 採集量の 99\%を超えた.アシナガゴカイの垂直分布は10 $20 \mathrm{~cm}$ に極大があるが，50 60 cm でも多くみられた.

St. 5 ではアシナガゴカイと負毛類が 10 個体 $/ 0.1 \mathrm{~m}^{2}$ を超 え, 湿重量ではアシナガゴカイとチゴガニが $0.1 \mathrm{~g} / 0.1 \mathrm{~m}^{2}$ 以 上出現した．アシナガゴカイは全体の $88 \%$ を占め, その分 布は $20 \mathrm{~cm}$ 以浅に限られていた。

今回の調査で最も多くの測点で湿重量として高い値を示 したのはアシナガゴカイで, St. 2 から 5 の 4 測点で優占種 となっており，これら 4 測点の平均では， 1,128 個体 $/ \mathrm{m}^{2}$, $86.4 \mathrm{~g} / \mathrm{m}^{2}$ であった。本種の出現は，底質粒子では砂泥から 軟泥まで，塩分濃度では約 10３0 psu の広篹囲におよび， また Ehが-200mV 以下の底泥からも出現し還元化に対し ても高い耐忍性を示した. 一方, 同じゴカイ科 (Nereididae）のイトメは St. 1 の比較的好気的な細砂底でのみ出現 し,ここでの現存量は 950 個体 $/ \mathrm{m}^{2}, 495 \mathrm{~g} / \mathrm{m}^{2}$ に達した.

また, マクロベントス密度は底質下部ほど減少する傾向 にあったが，すべての測点で50 60 cm 層でも出現してお り（Fig. 6), 谷津干潟のマクロベントスの底泥内での分布 は，干潟面より $60 \mathrm{~cm}$ 以深におよんでいた。

\section{考 察}

\section{底盤特性}

Eh は南部の St. 1 でのみプラス值であり，それ以外の測 点では $10 \mathrm{~cm}$ 以浅の表層を例外としてマイナス値であった (Fig. 4). Eh が-150 mV 以下の特に著しい還元状態は St. $3,4,5$ の表層以外で測定されたが, その値はわが国の主要 な干潟の下限値 $-100 \mathrm{mV}$ （桑原 1985）より低く, 谷津干 潟が有機污濁の進行した干潟であることを裹付けている. これは家庭排水を主源とした有機物の供給が多いことのあ らわれであろう。一般的にこのような底泥還元化の進行は, 底生動物の底泥内での生息可能深度の滅少，ならびに酸素 不足と硫化物の存在による生育阻害により，生息可能生物 種の隇少，極端な場合には無底生動物状態をもたらす (Pearson \& Rosenberg 1978). 有機污濁の進行した東京湾奥 部でも海底の負酸素化と同時に底質の還元化も進行してお り，Ehの低下とともにベントスの出現種数や群集多様度 は滅少の傾向にあり（風呂田 1986; 桑原 1986), $-167 \mathrm{mV}$ 以下の底泥ではマクロベントスの出現がみられない場合も ある（風呂田 1986）。

今回の調査では, St. 1 のみで Eh が全深度にわたってプ ラス値を示し，イトメ優占のマクロベントス集団が観察さ れた（Table 1，Fig. 6)。イトメは有機污濁の見られない小 

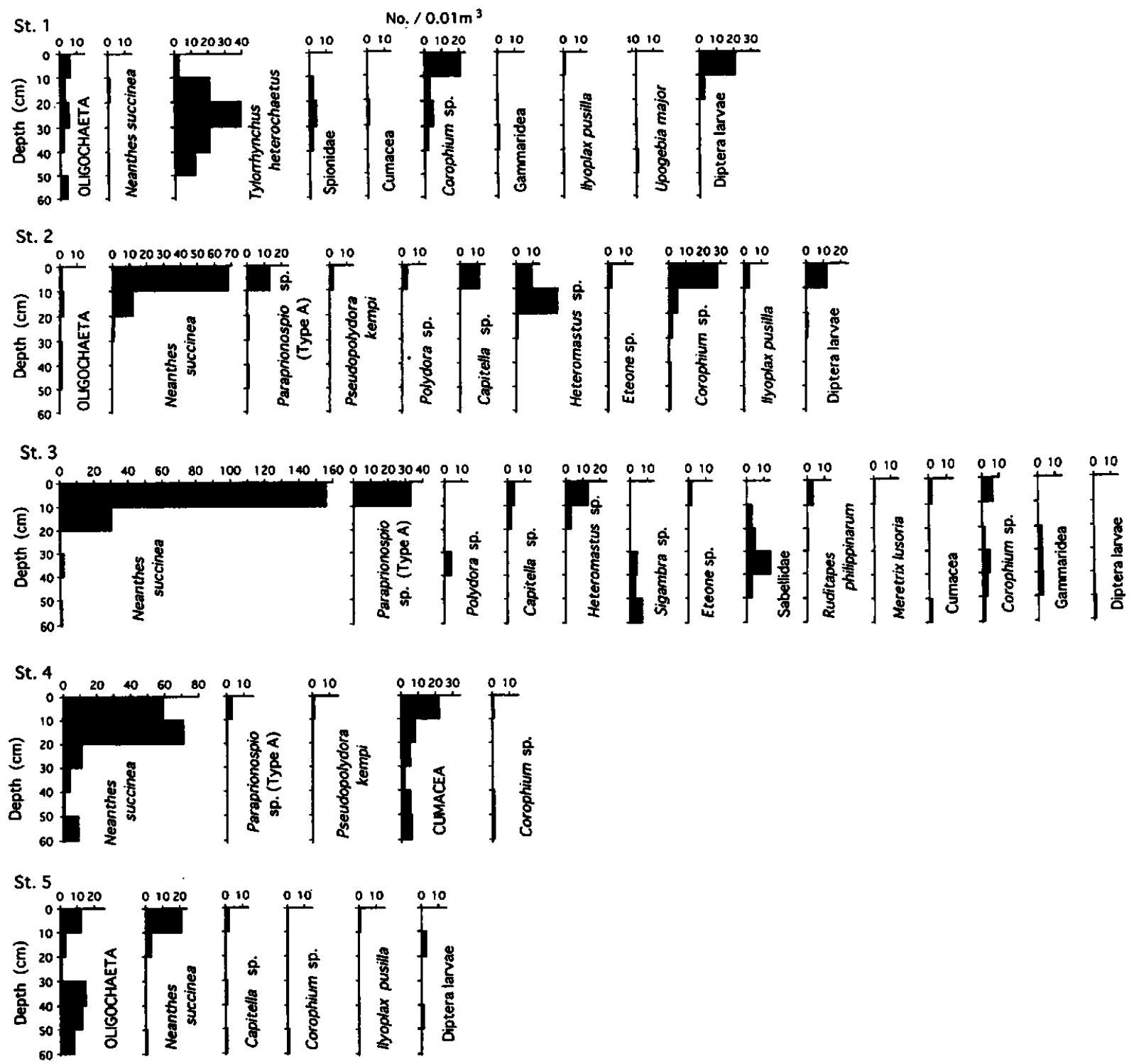

Fig. 6. Distributions of macrobenthic animals in the sediment column in the Yatsu Tidal Flat.

梄川河口湿地の泥底でも，底泥表面下 $30 \sim 40 \mathrm{~cm}$ の比較的 深い位置を中心に生息しており（風呂田 1996a），本種の谷 津干潟における出現域の限定は底泥の還元化に起因すると 思われる。

底泥表面下 $10 \mathrm{~cm}$ 以深の還元化は St. 3, 4, 5 で著しかっ た (Fig. 4). 底泥表面 $(0 \sim 10 \mathrm{~cm})$ までマイナス值であっ たSt. 4 と 5 ではべントス種数は少なく, 特に家庭排水の 影響を蚛く受け，より還元化していたSt. 5 では湿重量も 全測点中最小值を示した. 一方, St. 3 では最深部（50 60 $\mathrm{cm})$ の Ehは全調查結果中最低の $-287 \mathrm{mV}$ を示し, 極端 な還元状態にあったが, 表層 $(0 \sim 10 \mathrm{~cm})$ は $+57 \mathrm{mV}$ とや や好気的で,ここでは種類および個体数において全測点中 最も豊富なベントスが出現した。これらのことは, 干潟に おいては表面を含む底泥全体の還元化の進行はマクロベン トス群集の質および量的衰退をもたらすが, 底泥表面が Eh
でプラスとなる程度の好気的な状態であれば，有機物の供 給が多い干潟においても比較的豊富なマクロベントス群集 が維持されることを示している．また谷津干潟の底泥の大 部分が強い還元状態にあるにもかかわらず東京湾奥部海底 のような無底生動物状態に至っていないのは，干潟におけ る底質表面での微小藻類による酸素生産と, 定期的な干出 による大気中からの酸素供給, ならびに豊富な酸素を含む 海水の冠水により，底質表面に恒常的に酸素供給が継続さ れる結果であろう。

\section{マクロベントス出現程}

本調査で谷津干潟では確認された種ならびに群の総数は 19 であった。この干潟が閉鎖環境となった約 1 年後の調査 （1974 75 年）では多毛類の詳細な同定を行なえば生息、 クロベントスは約 15 種と推定されており（干潟研究会 
1975），本調查時やや增加したことになる．前回の調査で は出現したが本調査では探集されなかった種は，ムロミウ ミナナフシ Cyathura muromiensis Nunomura（報告ではウミ ナナフシであるが本種に訂正, 秋山章男 私信), コメッ キガニ Scopimera globosa de Haan, ヤマトオサガニ Macrophthalmus japonicus (de Haan), イソガニ Hemigrapsus sanguineus (de Haan), ウミニナ Batillaria multiformis (Lischke)，ミズヒキゴカイ Cirriformia tentaculata (Montagau）である。一方本調查で新たに確認された種は，前回 同定が不十分であった多毛類を除けば，アサリ，ハマグリ Meretrix lusoria (Röding) (稚貝 1 個体のみ), クーマ類 Cumacea, ドロクダムシの 1 種 Corophium sp., アナジャコ Upogebia major (de Haan) である.

今回探集されなかったイソガ二は本来転石や岩礁のカニ で干潟に出現することは極くまれであり，またコメッキガ ニ,ヤマトオサガニは調査年には目視では観察された。一 方ウミニナは 1985 年ならびに 1997 年に生息が確認されて いる(森田昌之・風呂田利夫 未発表). さらにミズヒキ ゴカイは泥質の干潟では一般的に出現がみられる種で， 1984 年の夏や 1985 年の 12 月には谷津干渴での出現が確認 されている(環境庁ほか 1996). したがってこれらの種が 本調查時点で谷津干潟からの消失したわけではない。しか し，ムロミスナウミナナフシは小梪川河口干潟など東京湾 の干潟に生息する生物であるが（風呂田 1996b），谷津干 渴では 1984 年, 1985 年ならびに 1995 年の調查でも出現し て抢らず（環境庁ほか 1996），本種個体群が 1985 年の時 点で谷津干潟から消失している可能性が高い。これとは逆 に，東京湾の砂質干潟では極めて豊富に生息するアサリが 今回出現したことは，干潟の一部が前回より砂澌化しつつ あることの反映かもしれない.

本調査の 10 年後の 1995 年の夏には 31 種群, 1996 年の 冬には39 種群のマクロベントスが採集されている(環境 庁ほか 1996)。本調査では出現せず，1995 年の夏あるいは 1996 年の冬に出現した主要種（平均 100 個体 $/ \mathrm{m}^{2}$ 以上もし くは調査測点の $1 / 3$ 以上の地点で出現した種）としては, 腹足類のカワグチツボ Falsicingula elegans (A. Adams)，〉 ラムシロガイ Reticunassa festiva (Powys)，二枚貝類ではホ トトギスガイ Musculista senhousia (Benson), 多毛類のコ ケゴカイ Ceratonereis erythraeensis Fauvel, Rhynchospio sp., Stleblospio benedicti japonica Imajima，がある. 出現種数は 採集面積に影響されるため各調査が谷津干潟のマクロベン トス総種数を正確に反映しているとは言えないものの, 比 較的頻繁に出現する小型の軟体動物や多毛類を中心に出現 種の増加が認められることから, 谷津干潟が現在の形状に なって以来，マクロベントス群集は一部消滅した種がある ものの全体としてはしだいに多様化しつつあると言えよう。

本調査の出現種群数 19 は前回の推定種群数 16 よりやや 增加したものの, 東京湾内の他の干潟で確認された種群： 小匮川河口干潟, 70 (大嶋 - 風呂田 1980); 新浜湖, 56
（風呂田 1980）；葛西，37（日本鳥類保護連盟 1975）と比 較して小さく, 谷津干潟のマクロベントス群集は明らかに 単調であることを示している，干潟マクロベントス群集は 干潟面の高さ（潮位）によって種構成が変化し（大鳿・風 呂田 1980; 風呂田 1996a), 谷津干潟面が全体的にほほ一定 の高さで占められていることもマクロベントス相が単調な 一因であろう.

\section{生物豆}

本調査の単位面積あたりのマクロベントス平均湿重量は $178 \mathrm{~g} / \mathrm{m}^{2}$ で, 東京湾の干潟の平均値約 $1 \mathrm{~kg} / \mathrm{m}^{2}$ (日本海洋学 会海洋環境問題委員会 1993, 参照) より低い。東京湾の 干潟でのマクロベントスの高い現存量は，海水中の有機馝 濁物を飭とするアサリなどの大型二枚貝類の豊富な生息に 支えられている（風呂田 1996a）. 東京湾の小桎川河口干潟 のマクロベントスの分布をみると，干潟下部では二枚貝の 豊富な生息により湿重量は $1 \mathrm{~kg} / \mathrm{m}^{2}$ 以上と高いが, 中部や 上部ではスナガニ科のカニやゴカイ科多毛類など堆積物食 者が多くなるがその湿重量は $100 \mathrm{~g} / \mathrm{m}^{2}$ 程度である（日本水 産資源保護協会 1992). その理由として風呂田（1996a） は，干潟上部は冠水時間が短いことと，海水が干潟前面を 通過してから上部に到達するため植物プランクトンなどの 畋濁態餌資源が途中で除去されるため, 動物の主要な餌を 干潟面の微小藻類による内部生産的に依存していることを あげている．また一般的に，アサリなどの干潟性の㦟濁物 食の二枚貝類は砂質底で多く, ゴカイ科多毛類などの堆積 物食者は泥底に多い. 谷津干潟面の潮位は最低干潮面から 䄪 $1 \mathrm{~m}$ の高さ（T.P. $-20 \mathrm{~cm}$ ）は潮間帯中部に相当し, 干潟 としては堆積物者が優占しやすいがアサリなどの䋰濁物食 者にとっては分布上限域である (大嶋・風呂田 1980)。し たがって, 干潟面の高さや含泥量の多い底質など谷津干潟 のもつ地形特性からみれば, この干潟では堆積物食者であ るゴカイ科多毛類が優占のマクロベントス群集が形成され やすい地形的環境であると言えよう。

本調査では, 谷津干潟における代表的マクロベントスは アシナガゴカイとイトメのゴカイ科多毛類であった. 本調 査の結果にみられるように，ゴカイ科多毛類は底質の極端 な還元化がないかきり深さ $50 \sim 60 \mathrm{~cm}$ でも多く生息してお り, 数 $10 \mathrm{~cm}$ 程度の浅い採泥ではその現存量を正確に把握 することは困難である。しかしながら三河湾の汐川干潟で は樑さ $10 \mathrm{~cm}$ の採泥にもかかわらず, 湿重量 $205 \mathrm{~g} / \mathrm{m}^{2}$ のゴ カイ Neanthes japonica (Izuka) が採集されており（日本鳥類 保讙連盟 1974), 本調査の谷津干潟のゴカイ科多毛類現存 量平均値 $168 \mathrm{~g} / \mathrm{m}^{2}$ は, 干潟域で特に高い現存量ではない。

\section{被捜畘特性}

アシナガゴカイやイトメなどのゴカイ科多毛類は谷津干 潟の主要鳥類であるシギ・チドリ類にとって最も良好な慨 資源である。本調查ではアシナガゴカイは底泥下 $20 \mathrm{~cm}$ 以 
浅に，イトメは $20 \sim 30 \mathrm{~cm}$ 付近に集中的に分布していた. シギ・チドリ類にとってかれらの嘴の長さが底泥表面下の 採食可能距離であり（Zwarts \& Wanink 1984）, 谷津干潟に みられる最も大型で長い嘴をもつタイシャクシギでは採食 可能深度は $15 \mathrm{~cm}$ 程度である（長谷川 1980）。このため生 息深度が深いイトメは摃食活動のためなどで表面に接近し た時以外は慨としては利用されにくいであろう。これに対 してアシナガゴカイは $20 \mathrm{~cm}$ 以浅に多く分布し, 慨として 比較的利用されやすいマクロベントスだろう。したがって, アシナガゴカイの現存量はシギ・チドリ類の採餌場として の谷津干潟利用に大きな影響を与えるだろう。

アシナガゴカイの属する Neanthes 属多毛類は, 底質表面 の堆積有機物を主な慨としており（Fauchald \& Jumars 1979; Tsuchiya \& Kurihara 1980), この有機物量がかれらの現存 量に影響を与えると考えられる。1995 年から 1996 年にか けての家庭排水の流入がすでに止められ外部からの有機物 負荷が本調査の時点より隇少した時点のマクロベントス調 査（深さ $50 \mathrm{~cm}$ まで採泥）では, 干潟の優占的多毛類はア シナガゴカイとともにゴカイが加わっており, 両種の底質 下 $50 \mathrm{~cm}$ までの平均湿重量は 1995 年 9 月で $20.7 \mathrm{~g} / \mathrm{m}^{2}$,

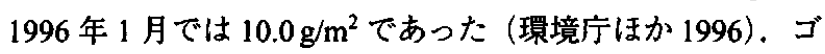
カイもアシナガゴカイと同様に底質表面近くに分布し（風 呂田 1996a），シギ・チドリ類の有効な飭資源と考えられる が, 本調査結果のアシナガゴカイ平均現存量 $69.1 \mathrm{~g} / \mathrm{m}^{2}$ と比 ベると, 1995 年から 1996 年の間に鳥飭としてのゴカイ科 多毛類の冬期資源量は $1 / 17$ に低下したことになる.ゴカイ 科多毛類の減少に対しアサリなどの二枚貝類の湿重量は本 調查で $0.3 \mathrm{~g} / \mathrm{m}^{2}, 1995 \sim 1996$ 年の冬の調査で $40.7 \mathrm{~g} / \mathrm{m}^{2}$ と明 らかな増加傾向にある. また, 本調査以後干潟面でのアオ サ類の生育が著しく，干潟面に堆積した場合には底泥表面 の嫌気化をもたらすようになった（長谷川昭仁 私信）。 このような海藻類を含む干潟マクロベントス群集構造の変 化は，当然ながら有機物や無機栄盖塩類そして酸素などの 物質循環過程の変化をもたらし，その結果としてゴカイ科 多毛類の生息が影響を受けた可能性も考えられる.しかし ながら, 家庭排水が流入していた本調查時点のほうがより 高いゴカイ科多毛類現存量があったことは, 家庭排水など から供給される有機物や無機栄養が直接的に，または干潟 面のバクテリアや付着微小藻類の生育など生物作用をとお して間接的にゴカイ科多毛類の生育を促していた可能性も 考えられる、したがって今後, 野鳥保護区としての谷津干 潟の環境保全を考える場合, 家庭排水による栄養物の供給 が干潟ベントス群集構造や現存量に与える影響を理解する 必要がある.

朝 辞 : 本論文をまとめるにあたって東京農業大学生物生産学 部の桑原連教授, ならびに東邦大学理学部の秋山章男教授から貴 重なご指摘を頂いた. 谷津干潟自然観察センター所長の長谷川昭 仁氏から谷津干淘の現状に関する情報の提供を受けた。匿名の査
読者からは適切なるご助言を頂いた。そして、Kevin Short 博士に は英語の校閲を頂いた。これらの皆様に心から感謝する.

\section{引用 文 献}

Fauchald, K. and P. A. Jumars 1979. The diet of worms: a study of polychaete feeding guildes. Oceanography and Marine Biology Annual Review, 17: 193-284.

風呂田利夫 1980 . 新浜湖の底生動物調查 (1979 年度)。千葉県新 浜保讙区生物調查報告書 $\mathrm{V}$, 新浜研究会, pp. 10-27.

風呂田利夫 1986. 東京湾千葉県内湾の底生・付着生物の生息状 況，特に群集の衰退が海底の酸欠の指標となり得る可能性につ いての検討 XIII. 千葉県臨海開発等に係る動植物影響調查 X. 千葉県環境部環境調整課, pp. 351-369.

風呂田利夫 1996a. 干潟底生動物の分布と摄食様式. 月刊海洋, 28: 166-177.

風呂田利夫 1996b. 干潟と浅瀬の生物. 沼田 㣀・風呂田利夫 (編), 東京湾の生物誌, 築地書館, 東京, pp. 45-73.

長谷川博 1980. 干潟の鳥の観察. 日本鳥類保荽連盟 (編), 自 然と楽しむ野外観察. 出版科学総合研究所, 東京, pp. 143-157. 干潟研究会 1975 . 開発の干潟に及ほす影製 II. 98 pp.

碇 京子・安部恭治. 伊豆永 巧 - 松本章宏 1996 東京湾奥部船 橋人工海浜におけるマクロベントス群集. 千葉県生物学会誌, 45: 7-11.

今村 均・羽原浩史・福田和国 1993. ミチゲーションとしての人 工干潟の造成，生態系と生息環境の追跡調査. 海岸工学論文 集, 40: 111-1115.

環境庁・ 千葉県・習志野市 1996. 谷津干潟環境調查報告書, 179 pp.

気象庁 (編) 1970. 海洋調查指針, 日本気象協会, $427 \mathrm{pp}$.

桑原 連 1985. 砂泥域の水質・底質環境. 水産土木, 21: 53-60.

桑原 連 1986. 横浜市沿岸域の底生動物相. 横浜の川と海の生物 (第 4 報)，pp. 227-250.

日本鳥類保讙連盟 1974. 干潟鳥類保護対策調査報告書, $64 \mathrm{pp}$. 日本鳥類保荽連盟 1975. 干潟鳥類保護対策調查報告書, 96 pp. 日本海洋学会 (編) 1986. 沿岸環境調查マニュアル・生物底質篇, 厚生社恒星閣, 東京, $266 \mathrm{pp}$.

日本海洋学会海洋環境問題委員会 1993. 閉鎖性水域の環境影響 セスメントに関する見解, 東京湾三番瀨埋め立てを例にして. 海の研究, 2: 129-136.

日本水産資源保護協会 1992. 漁場保全機能定量化事業報告書, 第一期とりまとめ, $249 \mathrm{pp}$.

大嶋 䦌・風呂田利夫 1980 . 小植川河口周辺における底生動物の 分布. 千葉県木更津市小桎川河口干潟の生態学的研究 I, 東邦 大学理学部海洋生物学研究室.千葉県生物学会 (編), pp. 4568.

Pearson, T. H. and R. Rosenberg 1978. Macrobenthic succession in relation to organic enrichment and pollution of the marine environment. Oceanography and Marine Biology Annual Review, 16: 229-311.

佐々木克之 1994a. 内湾および干潟における物質循環と生物生産 (8)，干潟域の物質循環. 海洋と生物，16: 122-128.

佐々木克之 1994b. 内湾および干潟における物質循環と生物生産 (12)，一色干潟の窒素循愣における二枚貝類の役割. 海洋と生 物, 16: 487-492.

Tsuchiya, M. and Y. Kurihara 1980. Effect of the feeding behaviour of macrobenthos on changes in environmental conditions of intertidal flats. Journal of Experimental Marine Biology and Ecology, 44: 8594.

Zwarts, L. and J. Wanink, 1984. How oystercatchers and curlews successively deplete clams. In Coastal Waders and Wildfowl in Winter, P. R. Evans, J. D. Goss-Custard and W.G.Hale (eds.), Cambridge University Press, London, pp. 69-83. 